\title{
Transformation Planning of Ecotourism Systems to Invigorate Responsible Tourism
}

\author{
Yun Eui Choi ${ }^{1}$ (D), Minsun Doh ${ }^{2}$, Samuel Park ${ }^{1}$ and Jinhyung Chon ${ }^{3, *}$ \\ 1 Department of Environmental Science and Ecological Engineering, Korea University, 145 Anam-ro, \\ Seongbukgu, Seoul 02841, Korea; choiuni313@korea.ac.kr (Y.E.C.); parksamuel@korea.ac.kr (S.P.) \\ 2 Department of Recreation, Park \& Tourism Administration, Western Illinois University, \\ Macomb, IL 61455, USA; m-doh@wiu.edu \\ 3 Division of Environmental Science and Ecological Engineering, Korea University, 145 Anam-ro, \\ Seongbukgu, Seoul 02841, Korea \\ * Correspondence: jchon@korea.ac.kr; Tel.: +82-10-8886-9963
}

Received: 31 October 2017; Accepted: 2 December 2017; Published: 5 December 2017

\begin{abstract}
The purpose of this study is to introduce transformation plans that can stimulate responsible ecotourism by using systems thinking to solve ecotourism problems in Korea. Systems thinking is a research method used to understand the operating mechanisms of the variables that influence an entire system, in order to identify its problems. The four types of ecotourism systems are classified as follows: low-infrastructure and resident-initiated, high-infrastructure and resident-initiated, high-infrastructure and government-initiated and low-infrastructure and government-initiated. These systems vary based on the need for tourism facilities and the form of governance. Each type of system is analyzed using the systems thinking process (dynamic thinking, causal thinking, feedback thinking, strategic thinking) at representative ecotourism sites in Jeollanam-do and the following transformation plans are proposed to improve the responsibility at the tourism sites: First, local residents will develop a system to manage and operate ecotourism ventures and establish cooperative governance structures to strengthen the local capacity. Second, ecotourism operators will improve the quality of their educational and interpretative programs and tourist information platforms in order to raise awareness of the responsibilities of ecotourists. Third, ecotourism systems that are improved through ecotourists' and tour operators' heightened senses of responsibility can sustain ecotourism independently. These transformation plans can be applied to policy proposals for revitalizing ecotourism, to guidelines for improving community resilience and to biological habitat protection plans. This study is meaningful in that it discusses the role of stakeholders in ecotourism planning and promoting responsible tourism and their role in utilizing and conserving natural resources accordingly.
\end{abstract}

Keywords: tourism systems; governance; sense of responsibility; natural resources; systems thinking

\section{Introduction}

For many years, ecotourism has been the focus of discussion as a way to conserve natural and ecological resources and to use them wisely. International organizations and agreements such as the United Nations Environment Programme, the International Union for Conservation of Nature, the UN World Tourism Organization (UNWTO), the Global Sustainable Tourism Council, the Convention on Biological Diversity and the Ramsar Convention are prime examples of organizations that consider ecotourism a means to conservation. In an increasing number of cases, natural areas worth protecting are under development as ecotourism attractions due to the growing perception of the positive economic impacts of ecotourism in both the public and private sectors. In South Korea, the Ministry of Environment led ecotourism development with a new article on the promotion of ecotourism (Article 41 of Chapter 4) that was added to the Natural Environment Conservation Act established in 
1997. The sites of ecotourism development in South Korea are mostly high-quality natural resources (e.g., national parks, ecosystem conservation areas, wildlife sanctuaries, wetlands conservation areas, migratory bird sanctuaries) that are legally restricted for private industrial activities, which has led governmental organizations to initiate ecotourism development. Organizations such as the Korea Forest Service, the Ministry of Agriculture, Food and Rural Affairs, the Ministry of Marine Affairs and Fisheries, the Ministry of Culture, Sports and Tourism and other local self-governing bodies also try to blend existing types of nature-based tourism (such as mountain tourism, rural tourism, marine tourism and local festivals) with ecotourism. However, in their hasty adoption of ecotourism, these agencies do not align with the global trend and fail to consider the fundamental principles of ecotourism development and its potential for local economic vitalization [1].

The International Ecotourism Society, a nonprofit organization established by experts and specialists from ecotourism-related fields, represents global ecotourism businesses and natural resource conservation organizations. It aims to set and disseminate a commonly understood definition of ecotourism and it published a revised up-to-date definition in 2015. It states that ecotourism is

"responsible travel to natural areas that conserves the environment, sustains the well-being of the local people and involves interpretation and education" [2].

Based on this definition, the aims of ecotourism are as follows: The first aim is to induce managers and operators to voluntarily conserve the natural environment through education and interpretation instead of tourism infrastructure development [3-5]. The second is to strengthen resident-centered local restoration through respect for the local culture, resident solidarity, nurturing exchanges between residents and tourists, local economic revitalization and so forth $[4,6]$. The third is to instill a sense of responsibility for the environment, society and the economy among all stakeholders, including tourists, managers, operators and residents [3,7-9]. In this sense, ecotourism shares the same foundation as responsible tourism in that it conforms to sociocultural, economic and environmental sustainability $[10,11]$. It has been 20 years since ecotourism was implemented in South Korea but it is experiencing several problems, such as saturated tourism facilities development, noise pollution due to tourism activities and overuse; insufficient attention is devoted to addressing issues related to environmental capacity, profit-centered development, a lack of information, interpretation and programming and conflicts between residents and land owners within protected areas [3,12]. To overcome these issues, responsible tourism should be a prerequisite for proper management of ecotourism attractions [13], as it requires ethical and moral behavior in environmental and tourism-related activities from all tourism stakeholders. A strong sense of responsibility among tourism stakeholders is essential for natural resource protection and prompt recovery by responsible parties if damages occur [14]. Responsible tourism can also enhance residents' income level with an even distribution of tourism profits, which can also be utilized for ecosystem restoration $[15,16]$. In this sense, the difficulties and problems associated with ecotourism development can be solved when it is based on responsible tourism development and the common value of ecotourism that the world aims to achieve can be recognized.

To apply responsible tourism to the current ecotourism development conditions in South Korea, it should be understood in the context of a tourism system that considers the complex socio-economic interests of tourism stakeholders, government policies and the ecosystem [3]. The tourism system refers to a functional structure comprising supply and demand components that influence one another [17]. An ecotourism system is a type of tourism system that forms complex mutual relationships among the factors that affect wildlife habitat environments and the restoration of local areas within an ecotourism destination [3]. Important factors to consider in ecotourism systems are (1) the demand side, or the level of demand for tourism facilities determined by tourists' sense of responsibility toward nature and their intention to cope with inconveniences in nature [18]; and (2) the supply side, or the process of governance formation led by managers and operators [19]. Issues resulting from the ecotourism system can be identified by understanding the social aspects of the ecosystem that are influenced by the dynamic relationship between ecotourists and operators. Problems associated with the structure of 
the ecotourism system or behavioral changes over time in business can be solved by transforming the system into a desirable system based on ecotourism principles [20]. Implementing a transformation plan can allow the ecotourism system to fulfill its purpose by invigorating responsible tourism.

Systems thinking has been applied in diverse research fields to analyze ecotourism systems and to create transformation plans $[3,12,21]$. Systems thinking is a research methodology that draws strategic points to solve problems in a system by comprehending the causal loop structure of the factors that comprise a complex system [22]. It enables an easy comparison of tourism phenomena that occur in different types of ecotourism attractions and it can be effective in executing a transformation plan to determine solution strategies for case-specific issues [3]. The purpose of this study is to explore problems by analyzing representative cases of different types of ecotourism systems utilizing systems thinking. To provide solutions to these problems, the study further aims to recommend new sustainable ecotourism systems driven by transformation plans that can stimulate responsible tourism. A literature review was performed to identify the conditions under which responsible tourism can be vitalized and to classify the types of ecotourism systems based on ecotourists' demand for tourism facilities and governance characteristics. In Section 3, four cases were chosen in Jeollanam-do in South Korea deemed to represent each type of ecotourism system, followed by the applications of the four stages of the systems thinking process. In Section 4, a causal map for each type of ecotourism system was constructed in accordance with systems thinking and a transformation plan for responsible tourism promotion was derived. In the last section, results were summarized and a proposal was made for a sustainable solution to solve the problems facing different types of ecotourism systems in South Korea.

\section{Literature Review}

\subsection{Types of Ecotourism Systems}

One way of classifying ecotourists is by measuring their sense of responsibility [18]. Ecotourists with a strong sense of responsibility perceive that the environment can be damaged by most types of tourism development (including ecotourism) and are against tourism development. In contrast, ecotourists with a weak sense of responsibility view humans and nature as equal or view humans in a higher position on the hierarchy; thus, they embrace most types of tourism development [18]. Thus, ecotourism projects are typically set at the midpoint, excluding the unrealistic extremes of both sides. Ecotourism is further divided into active and passive ecotourism [18]. Active ecotourism directly contributes to environmental conservation, while passive ecotourism merely attempts to minimize negative environmental impacts. It can also be classified as hard or soft ecotourism, depending on whether the tourists are willing to endure inconveniences during their ecotravel [13]. Hard ecotourists tend to have a high sense of responsibility and indulge in nature by restricting their use of tourism infrastructure in order to participate in active environmental conservation. They seek the true charm of nature, are satisfied with basic necessities and are willing to bear inconveniences [13,18]. In contrast, soft ecotourism is sought by those who are not willing to endure inconveniences but want nature experiences. Soft ecotourists would passively participate in environmental conservation by utilizing tourism facilities and trying to minimize the negative environmental impacts they exert on resources [13,18]. Therefore, depending on the level of investment in infrastructure, hard ecotourism can be characterized as low-infrastructure development and soft ecotourism can be characterized as high-infrastructure development. A low-infrastructure based type of ecotourism offers software-centered activities to support education and interpretation programs, while high-infrastructure based ecotourism relies on artificial tourism facilities such as accommodations, transportation, restaurants, experience centers and other amenities.

Ecotourism is supplied by managing and operating organizations such as the central government, local self-governing bodies, public agencies, residents, NGOs, research institutions and private agencies [19]. Based on the characteristics of the main operator, ecotourism led by the central government, local self-governing bodies, or public agencies is considered government-initiated ecotourism 
and ecotourism led by residents or private agencies is considered resident-initiated ecotourism. The formation of governance led by those who actually manage and operate ecotourism resources is necessary for their successful management. Governance refers to a forum for integrated policy making. It is a consultative group that mediates each stakeholder's strategic objectives and interests through official and unofficial communications [8,23]. Governance can be formed through a government-led top-down approach or a resident-led bottom-up approach. With the top-down approach, it is easy to disseminate the direction and goal of ecotourism development set by the central government. This approach can lead to fast results, as a large investment can be made in a short period of time. It is also relatively simple to provide consulting opportunities to residents through cooperation with experts. With this approach, however, considerations of the unique characteristics of the specific attraction, tourist demand, resident participation and discussions on the distribution of income may be undermined. The bottom-up approach may require more time and costs to find the local uniqueness and reach a resident consensus but it can enable community participation and facilitate discussions on income distribution.

In this study, ecotourism systems were categorized by combining ecotourists' demand for tourism facilities and the governance formation method on the supply side. Tourism facility development can negatively affect the quality of the environment and thus should be minimized for the long-term prosperity of ecotourism. In this sense, the level of tourism infrastructure development was set as one criterion and the type of managing/operating body was the other criterion. The four types of ecotourism systems that emerge from these criteria are low-infrastructure and resident-initiated, high-infrastructure and resident initiated, high-infrastructure and government-initiated and low-infrastructure and government-initiated.

\subsubsection{Low-Infrastructure and Resident-Initiated}

Low-infrastructure and resident-initiated ecotourism systems are found in areas with a restricted infrastructure development that limits population growth. Examples include areas around the Demilitarized Zone, water source protection areas, wetlands conservation areas, natural environment conservation areas and ecosystem conservation areas. The law restricts land-use changes in these areas and thus protects their natural environment and ecosystem. In turn, they provide excellent tourism resources. This type of system provides educational and interpretive programs that have the lowest impact on the environment and nature-based programs tend to be directly operated by residents in the form of an NGO or a residential community [6,24]. In addition, it administers resident-led ecotourism programs that increase income and promote sustainable community development through unconstrained communication among residents [14].

\subsubsection{High-Infrastructure and Resident-Initiated}

High-infrastructure and resident-initiated ecotourism systems are found in experiential villages designated by the Promotion of Mutual Exchange between Cities and the Agricultural or Fishing Villages Act. Examples include farming and recreational villages operated by the Ministry of Agriculture Food and Rural Affairs, fishing villages by the Ministry of Marine Affairs and Fisheries and mountain eco-villages by the Korea Forest Service. In fishing villages, residents cooperate and utilize the natural environment, fishing industry resources and other available resources to offer a variety of programs and experiential opportunities for urban residents [25]. Farming villages and mountain eco-villages are operated in a similar manner. These experiential villages may incur investment during the early stage of development because it requires infrastructure such as experience centers, accommodations, restaurants and parking spaces within the village. The villages also bear high operation costs and efforts for the continued management of facilities. However, most villages experience difficulties in sustaining themselves due to a lack of resident competence and cooperation with consultants and the local government [26]. Experiential programs in fishing villages are based on natural resources such as tideland; thus, they are responsible for preserving the ecological environment on which the 
ecotourism is based [26]. In a sense, farming, fishing and mountain villages are constrained in securing both primary and tertiary industries simultaneously. The sustainable prosperity of these villages requires cooperation among the local government, experts and residents and the establishment of convergence-composite industries.

\subsubsection{High-Infrastructure and Government-Initiated}

A primary example of the high-infrastructure and government-initiated type of ecotourism system is a natural resource-based hallmark event operated by local government. Environmental festivals such as the Hampyeong Butterfly Festival and the Hwacheon Sancheoneo (mountain trout) Ice Festival use natural resources such as animals, plants, insects, mountains and rivers to enhance the destination image by promoting the areas' purity and raising awareness of environmental protection [27]. These events can also promote local economic development through tourism. The output of festivals utilizing natural resources are constrained to occur in a relatively short period of time (ranging from 1 week to 2 months), as they reflect the resources' climate and geographic characteristics. Therefore, this type of ecotourism system requires intensive investment in funding and facilities [27].

\subsubsection{Low-Infrastructure and Government-Initiated}

Low-infrastructure and government-initiated ecotourism systems tend to be developed in officially designated areas such as ecological and scenery conservation areas, wetlands conservation areas and national parks. With high level of legal intervention, ecotourism projects are typically operated by the central government, its affiliated organizations, or local self-governing bodies. Areas that are designated by environmental policy-related regulations as having high-quality landscapes and wildlife habitats worth preserving are attractive ecotourism resources. However, because development is restricted in these designated areas, they face difficulties in developing tourism-related facilities. Therefore, natural landscape viewing as well as educational and interpretative programs are offered to small groups instead of experiential or recreational activities [28]. Natural environment interpreters trained through the Natural Environment Conservation Act work in ecologically superior areas (e.g., national parks, wetlands conservation areas, ecological and scenery conservation areas) managed by the Ministry of Environment, while forest education specialists trained through the Forest Education Promotion Act work in areas operated by the Korea Forest Service (e.g., recreation forests, arboretums, urban forests).

\subsection{Considerations for Invigorating Responsible Tourism}

A paradigm shift from mass tourism to alternative tourism hit the mainstream around the 1980s. Ecotourism was defined as travel to unharmed natural areas to enjoy cultural heritage, natural beauty and/or wildlife [29]. The early stages of ecotourism focused mostly on providing experiences to ecotourists and did not pay attention to providing residents with benefits associated with the tourism industry [30]. As a way to overcome this issue, the UNWTO addressed the need for responsible tourism in an alternative tourism seminar held in 1989 [31]. Responsible tourism respects the interests of all stakeholders, including the local environment and culture and requires responsible behavior from tourists $[9,13,32]$. From the time the UNWTO addressed the need for responsible tourism for the environment and the local area, many researchers and institutions began to include concepts such as environmental conservation, the well-being of residents and the return of the economic benefits of tourism to residents in their ecotourism definitions [33-36] and they emphasized that ecotourism is not only about enjoying natural resources. Ecotourism came to be defined as a type of alternative tourism that can realize sociocultural, economic and environmental sustainability and contribute to enhancing a sense of responsibility among ecotourism stakeholders.

Ecotourism stakeholders' responsible behavior is required for the invigoration of responsible tourism, as they play roles of supply and demand in ecotourism. With this in mind, many organizations, such as the UNWTO [37] and the City of Capetown [38], established codes of conduct to encourage 
ecotourists' responsible behavior. Tourists' role is stressed the most among the diverse tourism stakeholders mentioned in these codes. For example, the UNWTO's Global Code of Ethics for Tourism recommends that tourists learn about the destination and its regulations as much as possible before they engage in ecotravel, contribute to the conservation of destination areas' natural environment and cultural heritage, be open to other cultures and traditions and respect human rights [39]. Tourists should be willing to pay a fair price for ecotourism products, which enables higher returns to the local residents [40] and interested in purchasing locally produced tourism products [41]. Most ecotourists are aware of the negative sociocultural, economic and environmental impacts associated with tourist activities [42]. However, they are not familiar with practicing responsible tourism that can minimize the impacts. To vitalize responsible tourism, clear and concise responsible tourism codes of ethics for tourists must be established and disseminated [15,43].

Ecotourism suppliers are also expected to commit to responsible tourism [31]. Ecotourism businesses and local residents should respond to tourists' efforts to minimize the negative impacts of tourism [7]. Operators should minimize harm to wildlife habitats when locating tourism facilities, be able to manage natural resources by themselves and restrict tourist behavior to align with the area's environmental capacity. In addition, operators should consider natural resource conservation and the recovery of social networks as top priorities, rather than economic benefits [44]. As ecotourists are willing to pay a fair price for ecotourism products, providers are also liable for offering appropriate prices [45]. Finally, operators should (1) build a platform to provide information to tourists to learn about the destination's traditions, culture, natural resources and health status before they depart and (2) offer diverse pre-training and interpretive programs to prevent damage from tourist activities.

\section{Methods}

\subsection{Study Area}

Jeollanam-do selected ecotourism as its main vision for the effective conservation of its natural ecology in order to use it wisely. The Korea National Park Service and Jeonnam Cultural Tourism Foundation signed an agreement to invigorate ecotourism and they have made diverse efforts, such as supporting eco-friendly programming in farming, mountain and fishing villages. Therefore, it is expected to benefit from intensive financial investment and increased efforts in the near future. In this context, this study proposed a transformation plan for each type of ecotourism system in the hopes that Jeollanam-do will not experience the same problems and limitations as other ecotourism sites had to suffer from.

Jeollanam-do holds all four types of ecotourism system described in the literature review. The criteria used to select representative cases for each type of ecotourism system are as follows; (1) having won an excellence award from central office groups (ministries) or (2) having had a prosperous ecotourism business in the past five years. Four cases were chosen (Table 1), all of which were major areas selected by central organizations such as the Ministry of Environment, the Ministry of Marine Affairs and Fisheries and the Ministry of Culture, Sports and Tourism or those identified as outstanding cases in the related literature.

A village surrounding Suncheonman Bay in Suncheon-si (city) was chosen as a representative case for low-infrastructure and resident-initiated ecotourism systems, Goheung-gun (county) Annam fishing village for high-infrastructure and resident-initiated ecotourism systems, Hampeyong Butterfly Festival for high-infrastructure and government-initiated ecotourism systems and Jirisan National Park for low-infrastructure and government-initiated ecotourism systems. 
Table 1. Case area selection pool for ecotourism system analysis.

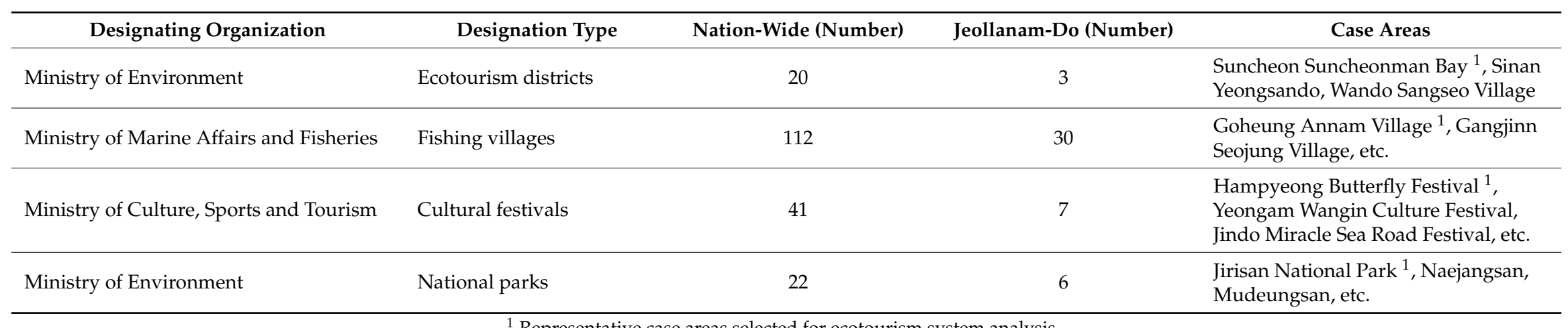

${ }^{1}$ Representative case areas selected for ecotourism system analysis. 


\subsection{Research Method}

Systems thinking is a research method used to understand the operating mechanisms of variables comprising an entire system in order to identify its problems. It also leads to the development of strategies to effectively transform the system for problem solutions [3]; thus, it is suitable for understanding tourism systems. The systems thinking process includes (1) dynamic thinking, which comprehends the current conditions of the system; (2) causal thinking, which confirms the causal linkages among the variables that comprise the system; (3) feedback thinking, which analyzes feedback loops formed by mutual interactions among the variables; and (4) strategic thinking, which transforms the system into a desirable one [46].

Dynamic phenomena that appear within the boundaries of the system are found in the dynamic thinking stage. In this study, the case areas' type of governance formation and associated conditions, such as the areas' operating system, ecotourists' behavior on site and means of natural resource conservation, were identified through research reports, online articles and news articles.

The tasks involved in the causal thinking stage included (1) selecting variables that explain dynamic phenomena within the system and (2) confirming causal linkages among the variables through a literature review and state of the case study site. Causal linkages among the variables are represented by arrows that show the direction of the relationship and plus $(+)$ or minus $(-)$ symbols that show the characteristics of the relationship. A plus $(+)$ symbol is added to the head of the arrow when the causal linkage between the two variables is in the same direction (i.e. when the dependent variable increases as the independent variable increases). A minus (-) symbol is inserted when the relationship between the two variables works in the opposite direction (i.e. when the dependent variable decreases as the independent variable increases).

In the feedback thinking stage, a causal map with feedback loops is constructed based on the causal linkages among the variables. This provides the basis for the analysis of the ecotourism system. Causal maps were created utilizing Vensim PLE version 6.3 software (Ventana Systems, Harvard, MA, USA). There are two types of feedback loops to consider in the analysis of causal maps: reinforcing loops and balancing loops. In a reinforcing loop, all the variables that belong to a loop change in the same direction; thus, it continues to only increase or decrease. In a balancing loop, a variable within a loop continues to increase or decrease, as influenced by other variables and converges as a specific value. This study analyzes system dynamics, including (1) the structure and the construction of ecotourism systems' feedback loops; (2) a dominant loop; and (3) transformation of the dominant feedback loop over time [46].

A transformation plan is recommended in the strategic thinking stage. It includes recognizing the problems of the system and identifying a strategic point to solve the problem with minimal effort and costs, which will guide the system in a desirable direction. A strategic point can be either a variable that harms the entire system in the long term or a variable that can change the feedback loop [3]. A transformation plan can be established in many ways, including (1) manually adjusting or eliminating the value of the strategic point; (2) removing a variable that affects the strategic point; (3) inserting a new policy variable; and (4) adjusting the dominant feedback loop [46]. To introduce a desirable transformation plan for each type of ecotourism system, a trategic point was set at principles against ecotourism while considering the conditions for responsible tourism vitalization.

The four stages of systems thinking should proceed with a feedback process by correcting the drawbacks of the previous step. This study went through a feedback process for each step to produce the transformation plans. The results are discussed in the next section. 


\section{Results and Discussion}

\subsection{Analysis of Low-Infrastructure and Resident-Initiated Ecotourism System: Case of Suncheon-si (City)} Ecotourism Council

\subsubsection{Analysis of Current Conditions of Suncheon-si Ecotourism Council Utilizing Dynamic Thinking}

Suncheonman Bay is situated on the coastal estuary of Suncheon-si (city) in Jeollanam-do (Province). It is a classic example of an ecotourism destination that has $22.6 \mathrm{Km}^{2}$ of tideland with a large reed colony and coastal wetlands that provide a habitat for more than 220 protected bird species, including hooded cranes, black-headed storks, oystercatchers and spoonbills. The Ministry of Environment designated Suncheonman Bay as an ecotourism development area in 2014 and the Suncheonman Bay Ecotourism Council was established as a corporation with support from Suncheon-si. The members of the organization include residents from Daedae village, Jangsan village, Geocha village and Nongju village. Founded in June 2015, the Suncheonman Bay Ecotourism Council Corporation has been working toward vitalizing Suncheonman Bay ecotourism by encouraging residents' voluntary initiatives, providing training to promote ecological sense of responsibility, educating village interpreters, supporting experiential programing for each village and providing assistance with forming a network comprising the central government, the local government, specialist groups and residents to develop resident-led cooperative governance. In addition, the council operates a website that provides tourists with information on the ecosystem of Suncheonman Bay, news on Suncheonman Bay ecotourism, ecological experience villages and ecotourism programs. All proceeds generated from ecotourism go to the local residents. In December 2015, the Ministry of Environment designated Dongcheon Estuary (located in Daedae village) as a wetlands conservation area. It was deemed significant as it bridges the major wetland ecological axis connecting coastal wetland (Suncheonman Bay), estuarine wetland (Dongcheon) and surrounding farmland with Suncheonman tidelands, which is also a wetland conservation area. The Suncheonman Ecotourism Council played a major role in holding public hearings and information sessions during the process of designation. With Dongcheon Estuary being registered as a Ramsar wetland in June 2016, it is highly likely that ecotourism will prosper in these villages.

4.1.2. Main Variables of Low-Infrastructure and Resident-Initiated Ecotourism System Based on Causal Thinking and Causal Links among Them

Variables were chosen that could fully explain the low-infrastructure and resident-initiated type of system led by the Suncheonman Bay Ecotourism Council and the characteristics of their causal relationships were analyzed (Table 2).

Table 2. Explanation of main variables of low-infrastructure and resident-initiated ecotourism system and the causal relationships among them.

\begin{tabular}{|c|c|c|c|c|}
\hline \multicolumn{2}{|c|}{ Main Variables } & \multirow{2}{*}{ Causal Link Mark } & \multirow{2}{*}{ Explanation } & \multirow{2}{*}{ References } \\
\hline Independent Variable & Dependent Variable & & & \\
\hline $\begin{array}{l}\text { Establishment of } \\
\text { cooperative governance }\end{array}$ & Resident capacity & + & $\begin{array}{l}\text { Cooperation among the } \\
\text { government, specialists and } \\
\text { residents enhances the capacity } \\
\text { of residents who operate } \\
\text { ecotourism business. }\end{array}$ & {$[8,31]$} \\
\hline Resident capacity & $\begin{array}{l}\text { Residents' sense of } \\
\text { responsibility }\end{array}$ & + & $\begin{array}{l}\text { Improved capacity of residents } \\
\text { enhances their sense of } \\
\text { responsibility toward ecotourism. }\end{array}$ & $\begin{array}{l}\text { State of the case } \\
\text { study site }\end{array}$ \\
\hline Resident capacity & $\begin{array}{l}\text { Quality of educational } \\
\text { and interpretive } \\
\text { programs }\end{array}$ & + & $\begin{array}{l}\text { The quality of educational and } \\
\text { interpretive programs is improved } \\
\text { when the capacity of resident } \\
\text { ecotourism operators is enhanced. }\end{array}$ & {$[3,24]$} \\
\hline
\end{tabular}


Table 2. Cont.

\begin{tabular}{|c|c|c|c|c|}
\hline \multicolumn{2}{|c|}{ Main Variables } & \multirow{2}{*}{ Causal Link Mark } & \multirow{2}{*}{ Explanation } & \multirow{2}{*}{ References } \\
\hline Independent Variable & Dependent Variable & & & \\
\hline Resident capacity & $\begin{array}{l}\text { Quality of information } \\
\text { provision platform }\end{array}$ & + & $\begin{array}{l}\text { The quality of information } \\
\text { provision platforms is improved } \\
\text { with the enhanced capacity of } \\
\text { residents who manage ecotourism } \\
\text { destination information. }\end{array}$ & $\begin{array}{l}\text { State of the case } \\
\text { study site }\end{array}$ \\
\hline $\begin{array}{l}\text { Residents' sense of } \\
\text { responsibility }\end{array}$ & $\begin{array}{l}\text { Natural resource } \\
\text { conservation }\end{array}$ & + & $\begin{array}{l}\text { Residents' sense of responsibility } \\
\text { toward ecotourism leads to natural } \\
\text { resource conservation. }\end{array}$ & [3] \\
\hline $\begin{array}{l}\text { Quality of educational } \\
\text { and interpretive } \\
\text { programs }\end{array}$ & $\begin{array}{l}\text { Tourists' sense of } \\
\text { responsibility }\end{array}$ & + & $\begin{array}{l}\text { Tourists who participate in } \\
\text { ecological education and } \\
\text { interpretive programs tend to have } \\
\text { a high sense of responsibility. }\end{array}$ & {$[5,24]$} \\
\hline $\begin{array}{l}\text { Quality of information } \\
\text { provision platform }\end{array}$ & $\begin{array}{l}\text { Tourists' sense of } \\
\text { responsibility }\end{array}$ & + & $\begin{array}{l}\text { An appropriate behavioral } \\
\text { process occurs with sufficient } \\
\text { information and knowledge on } \\
\text { ethical behavior. }\end{array}$ & [47] \\
\hline $\begin{array}{l}\text { Tourists' sense of } \\
\text { responsibility }\end{array}$ & $\begin{array}{l}\text { Natural resource } \\
\text { conservation }\end{array}$ & + & $\begin{array}{l}\text { Tourists' sense of responsibility on } \\
\text { ecotourism increases their } \\
\text { willingness to pay for natural } \\
\text { resource conservation, which lead } \\
\text { to natural resource conservation. }\end{array}$ & [43] \\
\hline $\begin{array}{l}\text { Natural resource } \\
\text { conservation }\end{array}$ & $\begin{array}{l}\text { Sustainability of } \\
\text { ecotourism }\end{array}$ & + & $\begin{array}{l}\text { The main tourism resource for } \\
\text { ecotourism is nature. Sustainability } \\
\text { of ecotourism is increased with } \\
\text { natural resource conservation. }\end{array}$ & [48] \\
\hline $\begin{array}{l}\text { Sustainability of } \\
\text { ecotourism }\end{array}$ & Number of ecotourists & + & $\begin{array}{l}\text { The number of ecotourists } \\
\text { increases with continued } \\
\text { ecotourism operation. }\end{array}$ & [48] \\
\hline Number of ecotourists & $\begin{array}{l}\text { Natural resource } \\
\text { conservation }\end{array}$ & - & $\begin{array}{l}\text { Pressure on nature increases } \\
\text { with an increased number of } \\
\text { ecotourists, which disrupts natural } \\
\text { resource conservation. }\end{array}$ & [42] \\
\hline Number of ecotourists & Local economy & + & $\begin{array}{l}\text { The local economy is vitalized as } \\
\text { the number of ecotourists increases } \\
\text { (increased profit). }\end{array}$ & [15] \\
\hline Local economy & $\begin{array}{l}\text { Residents' satisfaction } \\
\text { with ecotourism } \\
\text { operation }\end{array}$ & + & $\begin{array}{l}\text { Residents' satisfaction with } \\
\text { ecotourism is increased with the } \\
\text { visible growth in the local economy } \\
\text { through ecotourism. }\end{array}$ & [15] \\
\hline $\begin{array}{l}\text { Residents' satisfaction on } \\
\text { ecotourism operation }\end{array}$ & Resident capacity & + & $\begin{array}{l}\text { Residents voluntarily strive to } \\
\text { improve their capacity with an } \\
\text { increased level of satisfaction. }\end{array}$ & [49] \\
\hline $\begin{array}{l}\text { Designation as a } \\
\text { conservation area }\end{array}$ & $\begin{array}{l}\text { Tourists' sense of } \\
\text { responsibility }\end{array}$ & + & $\begin{array}{l}\text { Restrictions on activities due to } \\
\text { conservation area designation } \\
\text { enhances tourists' sense } \\
\text { of responsibility. }\end{array}$ & [50] \\
\hline $\begin{array}{l}\text { Designation as a } \\
\text { conservation area }\end{array}$ & $\begin{array}{l}\text { Natural resource } \\
\text { conservation }\end{array}$ & + & $\begin{array}{l}\text { Designated natural resources } \\
\text { are conserved through the } \\
\text { management of central and } \\
\text { local governments. }\end{array}$ & [50] \\
\hline $\begin{array}{l}\text { Designation as a } \\
\text { conservation area }\end{array}$ & $\begin{array}{l}\text { Residents' sense of } \\
\text { responsibility }\end{array}$ & + & $\begin{array}{l}\text { Restrictions on activities due to } \\
\text { conservation area designation } \\
\text { enhance residents' sense } \\
\text { of responsibility. }\end{array}$ & [50] \\
\hline
\end{tabular}

4.1.3. Analysis of Causal Map of Low-Infrastructure and Resident-Initiated Ecotourism System Based on Feedback Thinking

Figure 1 shows the causal map of the low-infrastructure and resident-initiated ecotourism system evidenced in the Suncheonman Bay Ecotourism Council. Three feedback loops were formed through the process: (1) damage to natural resources by tourists (Figure 1, B1); (2) natural resource management by local residents (Figure 1, R1); and (3) natural resource management by tourists 
(Figure 1, R2 and R3). In any type of ecotourism system, the increased number of tourists threatens natural resource conservation efforts; consequently, it reduces the sustainability of ecotourism and decreases the number of ecotourists. In the long term, however, a balancing loop (Figure 1, B1) is formed that positively affects conservation efforts through self-purification [12]. In this system, cooperative governance formed by the central government, the local self-governing body and residents in the early stage of tourism development support the enhancement of resident capacity, which reinforces loops R1 and R2. This implies that the formation of resident-led cooperative governance intensifies resident (supply) and ecotourists' (demand) sense of responsibility for natural resource conservation, which supports the sustainability of ecotourism [31].

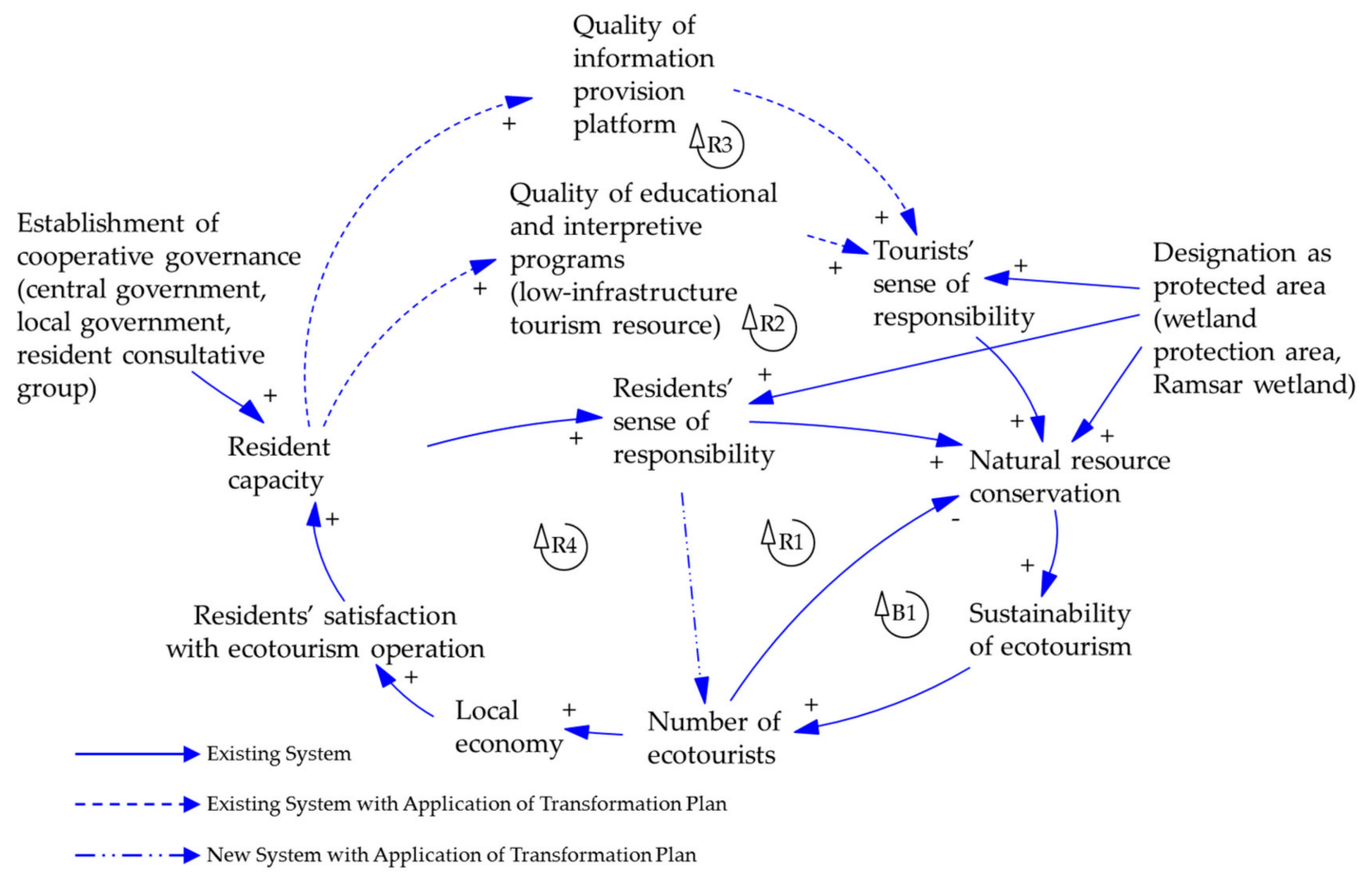

Figure 1. Causal map of low-infrastructure and resident-initiated ecotourism system.

With the spreading perception that ecosystem conservation can aid local economic growth through ecotourism, an increasing number of local self-governing bodies and communities are proposing protection area designation [51]. This designation contributes to the conservation of natural resources and can instill a sense of responsibility among residents and tourists. In this context, the designation of an area as a protection area reinforces the positive loop (Figure 1, R1-R3) and weakens the stagnant structure of ecotourism (Figure 1, B1).

4.1.4. Transformation Plan of Low-Infrastructure and Resident-Initiated Ecotourism System Based on Strategic Thinking

As observed above, the low-infrastructure and resident-initiated ecotourism system developed by the Suncheonman Bay Ecotourism Council has requirements for responsible tourism invigoration. The council has been in existence for more than 2 years but it is still behind in expanding staff to improve resident capacity and operate the systematic educational curriculum. This affects the quality of its website and its ecotourism-related educational and interpretive programs. As a part of the transformation plan to solve this issue, R2 and R3 (Figure 1) should be reinforced to enhance resident capacity by strengthening nationwide networking among ecotourism associations and providing expert training. In addition, the formation of R4 (Figure 1) can contribute to the invigoration of 
responsible tourism by limiting the number of participants in experiential programs that use natural resources (e.g., boating on the tidal flats, gathering tideland organisms).

4.2. Analysis of High-Infrastructure and Resident-Initiated Ecotourism System: Case of Annam Fishing Village, Goheung-gun (County)

\subsubsection{Analysis of Current Conditions of Goheung-gun Annam Fishing Village Utilizing} Dynamic Thinking

Annam Fishing Village, which is located in Goheung-gun, won the Grand Prize in the Fishing Village Progress Competition in 2015 hosted by the Ministry of Marine Affairs and Fisheries and operated by the Korea Fisheries Infrastructure Promotion Association. It was selected as a recipient of the Fishing Village Consultation Support Project by the Ministry of Marine Affairs and Fisheries and it receives specialist guidance from the Tourism Sciences Society of Korea. Annam Fishing Village operates its experiential village by organizing specialized operating groups separated by age, gender and main activities (e.g., a young adult group, women's guild, a senior citizens group, an operating committee). Fishing villages generate profit through sales of local products, experiential programs and accommodations and thus are highly reliant on infrastructure and amenities, such as local product stores, experience centers, parking lots, restrooms, inns, motels and camping grounds [25]. Annam Fishing Village is equipped with a parking lot, an information board, a footbath facility, a rest area, facilities to attract fish in order to catch them barehanded, an entrance to tideland and private room rentals. However, it is in need of amenities such as shower rooms and restrooms for use after tideland experiences such as cockling, barge fishing and catching fish with bare hands. The village has a website that is connected to the 'Sea N Tour' site operated by the Korea Fisheries Infrastructure Promotion Association with support from the Ministry of Marine Affairs and Fisheries. The village's homepage offers general information on the fishing village experiences provided by 'Sea $\mathrm{N}$ Tour' and information on experiential programs, local products, accommodations and restaurants exclusively offered in Annam Fishing Village.

4.2.2. Main Variables of the High-Infrastructure and Resident-Initiated Ecotourism System Based on Casual Thinking and Causal Links among Them

Variables were chosen that could provide a comprehensive explanation of the high-infrastructure and resident-initiated type of system adopted by Goheung-gun Annam Fishing Village and the characteristics of their causal relationships were analyzed (Table 3).

Table 3. Explanation of main variables of high-infrastructure and resident-initiated ecotourism system and the causal relationships.

\begin{tabular}{llll}
\hline \multicolumn{1}{c}{ Main Variables } & Causal Link Mark & \multicolumn{1}{c}{ Explanation } \\
\hline $\begin{array}{l}\text { Independent Variable } \\
\text { local government }\end{array}$ & Dependent Variable & Tourism facility & $\begin{array}{l}\text { Tourism facilities increase } \\
\text { with funding support from } \\
\text { local government. }\end{array}$ \\
\hline $\begin{array}{l}\text { Support from } \\
\text { local government }\end{array}$ & Local resident capacity & + & $\begin{array}{l}\text { Resident capacity can be enhanced } \\
\text { with increased support for resident } \\
\text { training and consulting from } \\
\text { local government. }\end{array}$ \\
\hline $\begin{array}{l}\text { Local resident capacity } \\
\text { study site }\end{array}$ & $\begin{array}{l}\text { Number of experiential } \\
\text { programs }\end{array}$ & + & $\begin{array}{l}\text { The number of experiential } \\
\text { programs increases with the } \\
\text { increased capacity of residents } \\
\text { operating experiential programs. }\end{array}$ \\
\hline $\begin{array}{l}\text { Number of } \\
\text { experiential programs }\end{array}$ & Tourism facility & $\begin{array}{l}\text { The tourism facilities needed for } \\
\text { experiential programs increase } \\
\text { with the increase in the number of } \\
\text { experiential programs. }\end{array}$ \\
\hline
\end{tabular}


Table 3. Cont.

\begin{tabular}{|c|c|c|c|c|}
\hline \multicolumn{2}{|c|}{ Main Variables } & \multirow{2}{*}{ Causal Link Mark } & \multirow{2}{*}{ Explanation } & \multirow{2}{*}{ References } \\
\hline Independent Variable & Dependent Variable & & & \\
\hline Tourism facility & $\begin{array}{l}\text { Natural resource } \\
\text { conservation }\end{array}$ & - & $\begin{array}{l}\text { Natural resource conservation } \\
\text { is interrupted with increased } \\
\text { tourism facilities. }\end{array}$ & [3] \\
\hline $\begin{array}{l}\text { Natural resource } \\
\text { conservation }\end{array}$ & $\begin{array}{l}\text { Sustainability of } \\
\text { ecotourism }\end{array}$ & + & $\begin{array}{l}\text { The main tourism resource for } \\
\text { ecotourism is nature. Sustainability } \\
\text { of ecotourism is increased with } \\
\text { natural resource conservation. }\end{array}$ & [48] \\
\hline $\begin{array}{l}\text { Sustainability of } \\
\text { ecotourism }\end{array}$ & Number of ecotourists & + & $\begin{array}{l}\text { The number of ecotourists } \\
\text { increases with continued } \\
\text { ecotourism operation. }\end{array}$ & [48] \\
\hline Number of ecotourists & $\begin{array}{l}\text { Natural resource } \\
\text { conservation }\end{array}$ & - & $\begin{array}{l}\text { Pressure on nature increases with } \\
\text { the increase in the number of } \\
\text { ecotourists, which disrupts natural } \\
\text { resource conservation efforts. }\end{array}$ & [42] \\
\hline Number of ecotourists & Local economy & + & $\begin{array}{l}\text { The local economy is vitalized as } \\
\text { the number of ecotourists increases } \\
\text { (increased profit). }\end{array}$ & [15] \\
\hline Local economy & $\begin{array}{l}\text { Residents' satisfaction } \\
\text { with ecotourism } \\
\text { operation }\end{array}$ & + & $\begin{array}{l}\text { Residents' satisfaction with } \\
\text { ecotourism is increased with the } \\
\text { visible growth in the local economy } \\
\text { through ecotourism. }\end{array}$ & [15] \\
\hline $\begin{array}{l}\text { Residents' satisfaction } \\
\text { with ecotourism } \\
\text { operation }\end{array}$ & Local resident capacity & + & $\begin{array}{l}\text { Residents voluntarily strive to } \\
\text { improve their capacity with an } \\
\text { increased level of satisfaction. }\end{array}$ & [49] \\
\hline
\end{tabular}

4.2.3. Analysis of Causal Map of High-Infrastructure and Resident-Initiated Ecotourism System Based on Feedback Thinking

Figure 2 shows the causal map of the high-infrastructure and resident-initiated ecotourism system evidenced in Goheung Annam Fishing Village. This ecotourism system forms (1) an ecotourism operation feedback loop that is focused on experiential programs (Figure 2, R5) and (2) a feedback loop on damage to natural resources due to tourism facilities (Figure 2, B2). As a part of the enhancement plan for Annam Fishing Village, Jeollanam-do's provincial government allocated a budget to support the office manager's payroll in order to improve the capacity of the local labor force and to expand parking spaces and shower rooms. This created a reinforcing loop (Figure 2, R5) that explains the process of how increased tourism facilities for experiential program operations invigorate ecotourism, which in turn contributes to the continued growth of the local economy. However, it may put pressure on suppliers to invest in more development in order to maximize profit. An increased tourism infrastructure causes damage to natural resources, which creates a balancing loop (Figure 2, B2) that restricts the sustainable growth of Annam Fishing Village. This means that the high-infrastructure and resident-initiated ecotourism system is limited in its growth, as shown by the addition of a balancing loop to the reinforcing loop. Limits to ecotourism system growth tend to depend on the limited carrying capacity of the natural environment. Therefore, the continuity of ecotourism requires a heightened interest in natural resource conservation [3]. 


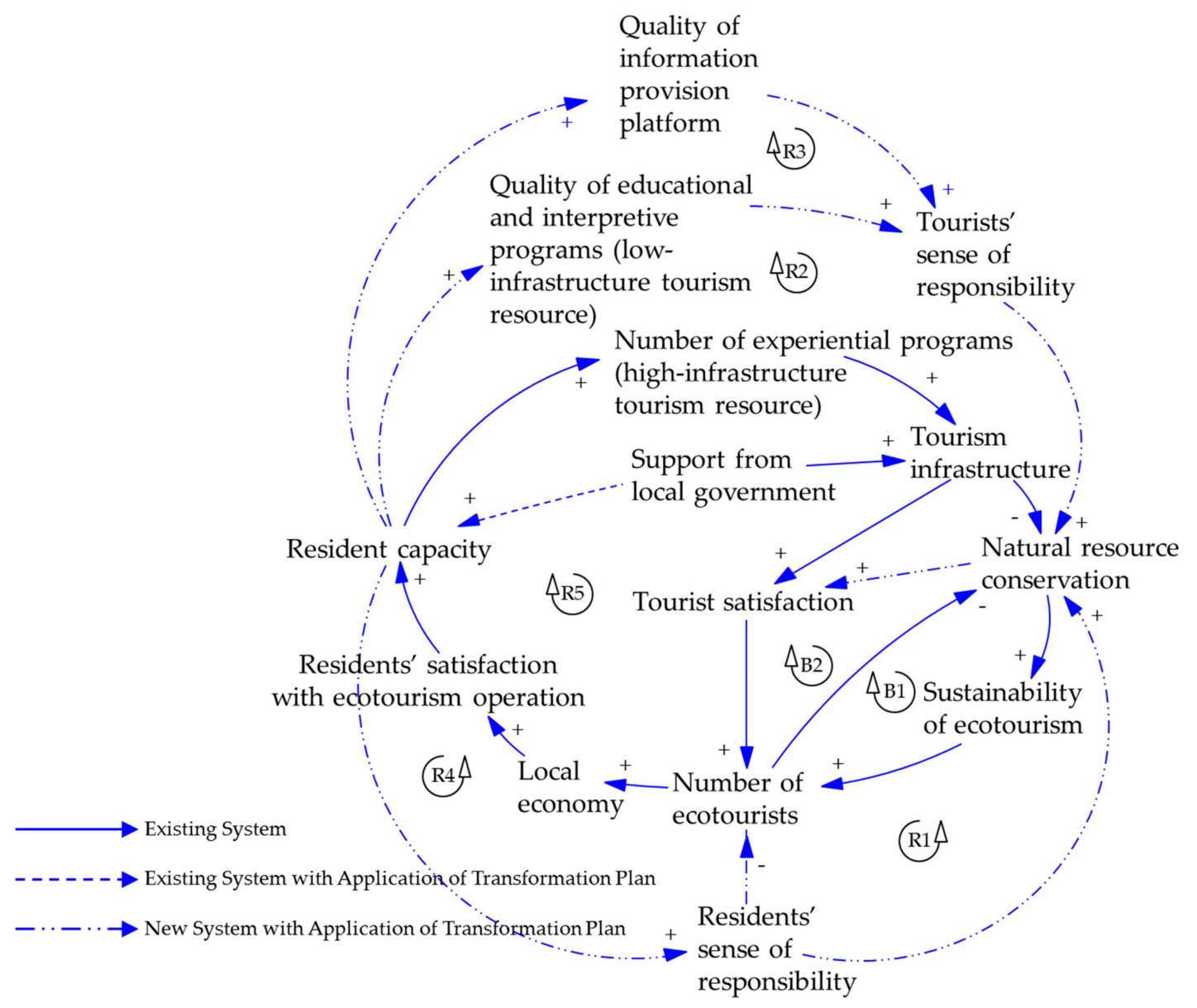

Figure 2. Causal map of high-infrastructure and resident-initiated ecotourism system.

4.2.4. Transformation Plan of the High-Infrastructure and Resident-Initiated Ecotourism System Based on Strategic Thinking

The high-infrastructure and resident-initiated ecotourism system represented by Goheung Annam Fishing Village lacks the means to generate a sense of responsibility among residents and tourists regarding the utilization of natural resources. It has a cooperative governance in which residents (1) form specialized operational organizations and (2) receive support from the local government and experts' consultation. However, the resident organization's sense of responsibility is relatively low because the support is limited to funding for payroll or facilities development. To solve this problem, a transformation plan was established (Figure 2, R1 and R4) to improve tourism software competitiveness [5,24]. For example, the local government's support should be expanded to (1) providing training to enhance an ecological sense of responsibility; (2) training talented village interpreters; (3) developing specialized experiential programs through resident participation; and (4) providing service training on information provision, guiding and interpretation.

Experiential ecotourism participants tend to be soft ecotourism tourists who have a lower sense of responsibility, are not willing to participate in active natural resource conservation and are less likely to endure inconveniences from a lack of tourism facilities. The transformation plan (Figure 2, R2 and R3) that was introduced includes provision of online information, pre-training for experiential program participation and education on possible inconveniences during the ecotourism experience. With the implementation of the new transformation plan, tourists' level of satisfaction may also increase if they become voluntary conservationists through training. 


\subsection{Analysis of High-Infrastructure and Government-Initiated Ecotourism System: Case of Hampyeong Butterfly Festival}

\subsubsection{Analysis of Current Conditions of Hampyeong Butterfly Festival Utilizing Dynamic Thinking}

Hampyeong Butterfly Festival is an ecotourism festival that has been hosted by Hampyeong-gun (County) since May 1999. Hampyeong-gun is an agricultural region that lacks industrial, tourism, or natural resources. To emphasize the environmental friendliness of its agricultural products, the festival chose butterflies as the theme of the event. This theme is familiar to many in the area, as Hampyeong-gun established an insect research lab in 1998 and began breeding and researching butterflies. A festival steering committee was established, followed by the development of the large Hampyeong Expo Park $\left(647,250 \mathrm{~m}^{2}\right)$ and continued investment for success. The image of Hampyeong-gun was transformed into an eco-friendly butterfly habitat and the region has recorded increased sales of local agricultural products due to the positive change in destination brand equity. However, in the early years of the festival, its profits leaked to businesses outside of the region instead of being returned to the residents and the festival experienced financial difficulties without support from the central government. Thus, the formation of cooperative governance by the central government, local government and residents was not smooth. As a solution, Hampyeong-gun reduced the scale of the festival and restricted sales of agricultural and specialty products only to those produced in the county in order to help direct the profit to the local community [27].

Butterflies used for the festival were mass-produced to align with the timing of the festival and were released at Hampyeong Expo Park, which is not a typical practice of natural resource use for ecotourism. Muju Firefly Festival is a similar type of festival that utilizes insects but it differs from the butterfly festival in many ways: (1) the festival ground is a firefly habitat designated as a Natural Monument; and (2) the program focuses on environmental education and first-hand experiences, such as letting fireflies loose and observing fireflies at night. In addition to the butterfly catching experience, the butterfly festival offers typical programs such as exhibitions, performances, productions and entertainment [3].

4.3.2. Main Variables of the High-Infrastructure and Government-Initiated Ecotourism System Based on Casual Thinking and Causal Links among Them

Variables were chosen that could fully explain the high-infrastructure and government-initiated type of system adopted by the Hampyeong Butterfly Festival and the characteristics of their causal relationships were analyzed (Table 4).

Table 4. Explanation of the main variables of the high-infrastructure and government-initiated ecotourism system and the causal relationships.

\begin{tabular}{|c|c|c|c|c|}
\hline \multicolumn{2}{|c|}{ Main Variables } & \multirow{2}{*}{ Causal Link Mark } & \multirow{2}{*}{ Explanation } & \multirow{2}{*}{ References } \\
\hline Independent Variable & Dependent Variable & & & \\
\hline $\begin{array}{l}\text { Funding from } \\
\text { Central Government }\end{array}$ & Festival operation budget & + & $\begin{array}{l}\text { Operating budget of the } \\
\text { festival increases with } \\
\text { increased financial support from } \\
\text { the central government. }\end{array}$ & $\begin{array}{l}\text { State of the case } \\
\text { study site }\end{array}$ \\
\hline Festival operation budget & $\begin{array}{l}\text { Number of experiential } \\
\text { programs }\end{array}$ & + & $\begin{array}{l}\text { Number of experiential } \\
\text { program increases with larger } \\
\text { operational budget. }\end{array}$ & [27] \\
\hline $\begin{array}{l}\text { Number of } \\
\text { experiential programs }\end{array}$ & Tourism infrastructure & + & $\begin{array}{l}\text { Tourism facilities needed for } \\
\text { experiential programs increase } \\
\text { with the increase in the number of } \\
\text { experiential programs. }\end{array}$ & $\begin{array}{l}\text { State of the case } \\
\text { study site }\end{array}$ \\
\hline $\begin{array}{l}\text { Number of } \\
\text { experiential programs }\end{array}$ & Tourist satisfaction & + & $\begin{array}{l}\text { Tourist satisfaction is improved } \\
\text { with the larger number of } \\
\text { experiential programs. }\end{array}$ & $\begin{array}{l}\text { State of the case } \\
\text { study site }\end{array}$ \\
\hline
\end{tabular}


Table 4. Cont.

\begin{tabular}{|c|c|c|c|c|}
\hline \multicolumn{2}{|c|}{ Main Variables } & \multirow{2}{*}{ Causal Link Mark } & \multirow{2}{*}{ Explanation } & \multirow{2}{*}{ References } \\
\hline Independent Variable & Dependent Variable & & & \\
\hline Tourist satisfaction & Number of ecotourists & + & $\begin{array}{l}\text { The number of tourists increases } \\
\text { with higher tourist satisfaction. }\end{array}$ & $\begin{array}{l}\text { State of the case } \\
\text { study site }\end{array}$ \\
\hline Tourism infrastructure & $\begin{array}{l}\text { Natural resource } \\
\text { conservation }\end{array}$ & - & $\begin{array}{l}\text { Natural resource conservation } \\
\text { is troubled with the increase in } \\
\text { tourism infrastructure } \\
\text { development. }\end{array}$ & [3] \\
\hline $\begin{array}{l}\text { Natural resource } \\
\text { conservation }\end{array}$ & $\begin{array}{l}\text { Sustainability of } \\
\text { ecotourism }\end{array}$ & + & $\begin{array}{l}\text { Ecotourism utilizes nature as the } \\
\text { main resource. Sustainability of } \\
\text { ecotourism is increased with } \\
\text { natural resource conservation. }\end{array}$ & [48] \\
\hline $\begin{array}{l}\text { Sustainability of } \\
\text { ecotourism }\end{array}$ & Number of ecotourists & + & $\begin{array}{l}\text { The number of ecotourists } \\
\text { increases with continued } \\
\text { ecotourism operation. }\end{array}$ & [48] \\
\hline Profit from the festival & Local government budget & + & $\begin{array}{l}\text { Local government profit increases } \\
\text { as festival income grows. }\end{array}$ & $\begin{array}{l}\text { State of the case } \\
\text { study site }\end{array}$ \\
\hline Local government budget & $\begin{array}{l}\text { Operating costs for } \\
\text { festival }\end{array}$ & + & $\begin{array}{l}\text { The following year's festival } \\
\text { budget increases with the increase } \\
\text { in the local government budget. }\end{array}$ & $\begin{array}{l}\text { State of the case } \\
\text { study site }\end{array}$ \\
\hline
\end{tabular}

4.3.3. Analysis of the Causal Map of the High-Infrastructure and Government-Initiated Ecotourism System Based on Feedback Thinking

Figure 3 shows the causal map of the high-infrastructure and government-initiated ecotourism system evidenced in the Hampyeong Butterfly Festival. This type of system forms a feedback loop that (1) vitalizes the eco-festival based on the amount of the operational budget supported by funding from the local government and the central government (Figure 3, R6) and (2) hinders the sustainability of ecotourism due to the loss of natural resource conservation opportunities as tourism facilities increase (Figure 3, B3). Similar to the high-infrastructure and resident-initiated ecotourism system, this system also experiences growth limitations due to the combination of the reinforcing loop and the balancing loop, although the reinforcing loop (R6) is more dominant than the balancing loop (Figure 3, B3) at the moment.

Government-initiated ecotourism projects tend to be easier to operate due to prompt budget allocation by the local government and the simplicity of the central government funding process. However, the quality of the festival and tourist satisfaction may continue to decline without sufficient budget allocation, which may result in the Sunset Law of the Culture Tourism Festival [52]. The threat to the sustainability of ecotourism is also a problem. The unique characteristics of the festival as an eco-festival will be lost by the expansion of the tourism infrastructure development without considering the conservation of butterflies and natural resources. This may eliminate the eco-friendly image of the festival in the long term; in turn, it may result in the decline of the destination image of Hampyeong's local agricultural and specialty products and ultimately become a barrier to local economic growth.

4.3.4. Transformation Plan of the High-Infrastructure and Government-Initiated Ecotourism System Based on Strategic Thinking

To prevent the problems described in the previous section, the proportion of the festival operating budget from the central government should be reduced and a transformation plan is needed to expand the local residents' financial investment and participation opportunities (Figure 3, R7). Resident participation includes the operation of experiential programs involving butterflies, environmental education programs (including butterfly breeding, interpretive programs associated with village traditions and culture) as well as the sales of local agricultural and specialty products. Direct investment 
and participation by residents can guide the immediate vitalization of the local economy through the redistribution of festival profits. Reducing the number of experiential programs that use tourism facilities and enhancing the quality of educational and interpretive programs by local residents can prevent the expansion of tourism facilities development and heighten tourists' sense of responsibility. This can maximize the outcomes of natural resource conservation efforts.

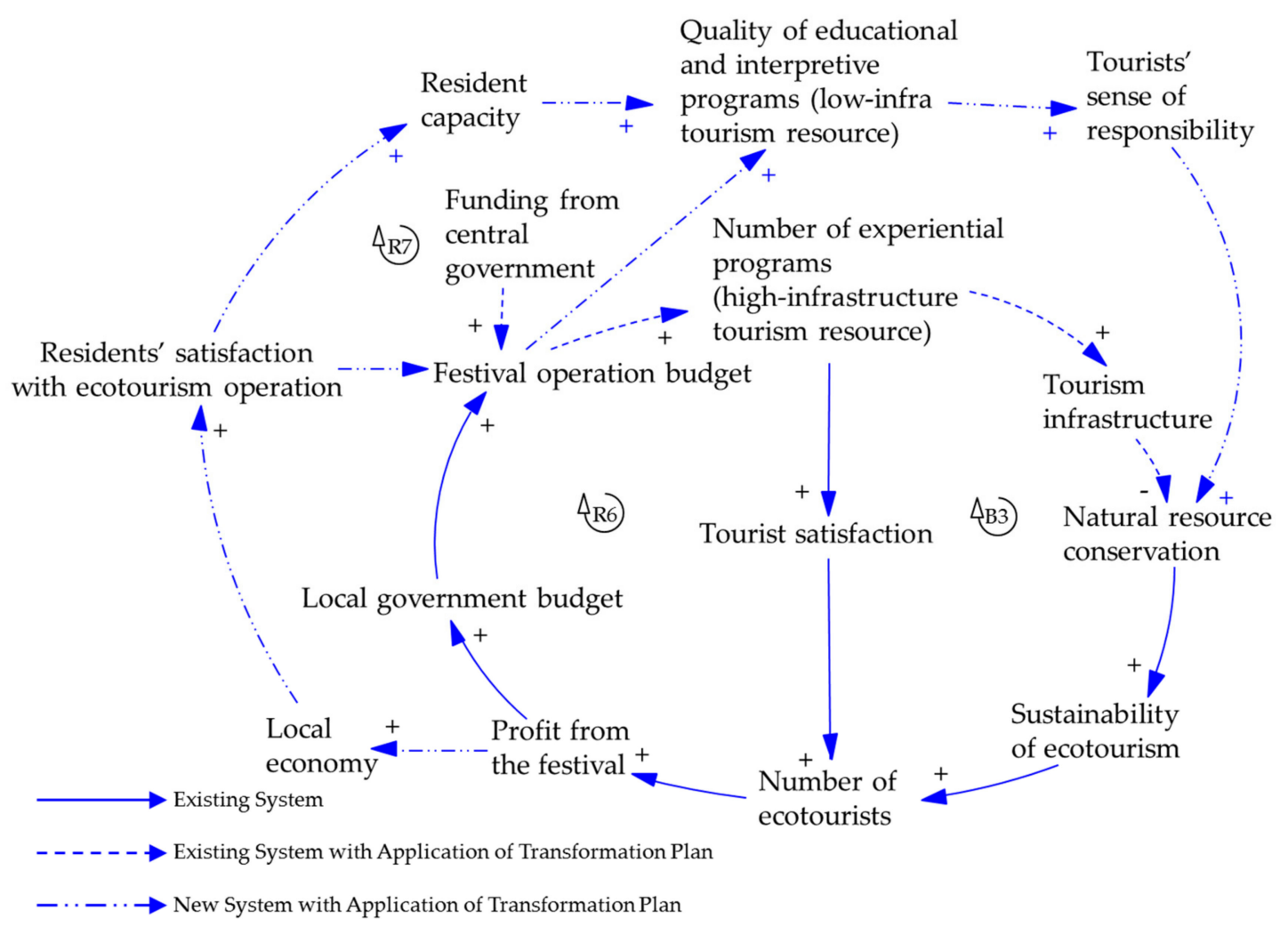

Figure 3. Causal map of the high-infrastructure and government-initiated ecotourism system.

\subsection{Analysis of the Low-Infrastructure and Government-Initiated Ecotourism System: The Case of Jirisan National Park}

\subsubsection{Analysis of the Current Conditions of the Jirisan National Park Utilizing Dynamic Thinking}

Ecotourism in national parks is operated by the Ministry of Environment, which designates national parks and oversees park management and the Korea National Park Service, its affiliated organization. Ecotourism in national parks is affected by related regulations, such as the Natural Parks Act and Natural Environment Conservation Act. Jirisan was South Korea's first national park, designated in 1967 and belongs to 3 provinces (Jeollanam-do, Jeollabuk-do and Gyeongsangnam-do). It is the largest national park in South Korea $\left(483.022 \mathrm{Km}^{2}\right)$ and it is mountainous. Ecotourism in Jirisan National Park is operated mainly in Jeollanam-do Gurye-gun, where the Korea National Park Service's Jirisan Eco Institute and Species Restoration Technology Institute are located. Jirisan Eco Institute supports ecological resource experiences and environmental education. It also operates an accommodations facility to run ecotourism that involves overnight stays. The main ecotourism programs include an experiential program on Jirisan Moon Bear (Asiatic Black Bear) ecology and restoration, temple culture experiences, historic houses experiences, Jirisan trail trekking, a Seomjingang River hydroecology field trip and so forth. These programs are led by environmental interpreters. The Species Restoration Technology Institute performs research and restoration projects on South Korea's endangered species on site. It has been restoring Jirisan Moon Bear in the national park since 2004 and it is operating eco-exhibitions and an eco-experience center related to the Moon 
Bear project, offering a variety of educational programs to ecotourists. In addition, the Korea National Park Service has been supporting resident guide programs and the Myeong-Pum Maeul (Villages of Excellence) project for residents' autonomous operation of ecotourism. Three resident guide programs and one Myeong-Pum Maeul have been implemented in Jirisan National Park to date. National park ecotourism operated by the Ministry of Environment and the Korea National Park Service offers quality information to ecotourists through online portals such as Korea National Park Ecotour [53] and Korea National Park Myeong-pum Maeul [54]. It actively responds to pre-, current and post-travel information requests, in addition to other requests.

4.4.2. Main Variables of the Low-Infrastructure and Government-Initiated Ecotourism System Based on Casual Thinking and Causal Links among Them

Variables were chosen that could fully explain the low-infrastructure and government-initiated type of system led by the Jirisan National Park and the characteristics of their causal relationships were analyzed (Table 5).

Table 5. Explanation of main variables of low-infrastructure and government-initiated ecotourism system and the causal relationships.

\begin{tabular}{|c|c|c|c|c|}
\hline \multicolumn{2}{|c|}{ Main Variables } & \multirow{2}{*}{ Causal Link Mark } & \multirow{2}{*}{ Explanation } & \multirow{2}{*}{ References } \\
\hline Independent Variable & Dependent Variable & & & \\
\hline $\begin{array}{l}\text { Establishment of } \\
\text { a regulation to } \\
\text { vitalize ecotourism }\end{array}$ & $\begin{array}{l}\text { Ecotourism-related } \\
\text { budget in the Ministry of } \\
\text { Environment }\end{array}$ & + & $\begin{array}{l}\text { The ecotourism-related budget in } \\
\text { the Ministry of Environment } \\
\text { increases with the establishment of } \\
\text { a regulation on ecotourism } \\
\text { vitalization (Article } 41 \text {, Natural } \\
\text { Environment Conservation Act). }\end{array}$ & $\begin{array}{l}\text { State of the case } \\
\text { study site }\end{array}$ \\
\hline $\begin{array}{l}\text { Ecotourism-related } \\
\text { budget in the Ministry } \\
\text { of Environment }\end{array}$ & $\begin{array}{l}\text { Ecotourism-related } \\
\text { budget in Korea National } \\
\text { Park Service }\end{array}$ & + & $\begin{array}{l}\text { The ecotourism-related budget in } \\
\text { Korea National Park Service } \\
\text { (ecotourism operation } \\
\text { organization) increases } \\
\text { with the increase in ecotourism- } \\
\text { related budget in the Ministry } \\
\text { of Environment. }\end{array}$ & $\begin{array}{l}\text { State of the case } \\
\text { study site }\end{array}$ \\
\hline $\begin{array}{l}\text { Ecotourism-related } \\
\text { budget in Korea National } \\
\text { Park Service }\end{array}$ & $\begin{array}{l}\text { Ecotourism development } \\
\text { plan in national parks }\end{array}$ & + & $\begin{array}{l}\text { Ecotourism development } \\
\text { plans in national parks increase } \\
\text { with the increase in the ecotourism- } \\
\text { related budget in Korea National } \\
\text { Park Service. }\end{array}$ & $\begin{array}{l}\text { State of the case } \\
\text { study site }\end{array}$ \\
\hline $\begin{array}{l}\text { Ecotourism development } \\
\text { plan in national parks }\end{array}$ & $\begin{array}{l}\text { Eco Institute } \\
\text { development project }\end{array}$ & + & $\begin{array}{l}\text { An increase in the number of } \\
\text { ecotourism development plans in } \\
\text { National Parks increases Eco } \\
\text { Institute development projects. }\end{array}$ & $\begin{array}{l}\text { State of the case } \\
\text { study site }\end{array}$ \\
\hline $\begin{array}{l}\text { Ecotourism development } \\
\text { plan in national parks }\end{array}$ & $\begin{array}{l}\text { Resident guide program } \\
\text { support project }\end{array}$ & + & $\begin{array}{l}\text { The number of resident guide } \\
\text { program support projects } \\
\text { increases with the increase in } \\
\text { ecotourism development plans } \\
\text { in national parks. }\end{array}$ & $\begin{array}{l}\text { State of the case } \\
\text { study site }\end{array}$ \\
\hline $\begin{array}{l}\text { Ecotourism development } \\
\text { plan in national parks }\end{array}$ & $\begin{array}{l}\text { Villages of Excellence } \\
\text { designation project }\end{array}$ & + & $\begin{array}{l}\text { Villages of Excellence designation } \\
\text { project grows with the increase in } \\
\text { ecotourism development plans in } \\
\text { national parks. }\end{array}$ & $\begin{array}{l}\text { State of the case } \\
\text { study site }\end{array}$ \\
\hline $\begin{array}{l}\text { Resident guide program } \\
\text { support project }\end{array}$ & Resident capacity & + & $\begin{array}{l}\text { The capacity of resident } \\
\text { ecotourism operators is enhanced } \\
\text { through the resident guide } \\
\text { program support project. }\end{array}$ & [31] \\
\hline $\begin{array}{l}\text { Villages of Excellence } \\
\text { designation project }\end{array}$ & Resident capacity & + & $\begin{array}{l}\text { The capacity of residents is } \\
\text { enhanced through investment in } \\
\text { the Villages of Excellence } \\
\text { designation project. }\end{array}$ & [31] \\
\hline Resident capacity & $\begin{array}{l}\text { Quality of educational } \\
\text { and interpretive } \\
\text { programs }\end{array}$ & + & $\begin{array}{l}\text { The quality of educational and } \\
\text { interpretive programs is } \\
\text { enhanced with the enhancement } \\
\text { of resident capacity. }\end{array}$ & [3] \\
\hline
\end{tabular}


Table 5. Cont.

\begin{tabular}{|c|c|c|c|c|}
\hline \multicolumn{2}{|c|}{ Main Variables } & \multirow{2}{*}{ Causal Link Mark } & \multirow{2}{*}{ Explanation } & \multirow{2}{*}{ References } \\
\hline Independent Variable & Dependent Variable & & & \\
\hline $\begin{array}{l}\text { Eco Institute } \\
\text { development project }\end{array}$ & $\begin{array}{l}\text { Employment of natural } \\
\text { environment interpreters }\end{array}$ & + & $\begin{array}{l}\text { The employment of natural } \\
\text { environment interpreters increases } \\
\text { with increase in the Eco Institute } \\
\text { development project. }\end{array}$ & $\begin{array}{l}\text { State of the case } \\
\text { study site }\end{array}$ \\
\hline $\begin{array}{l}\text { Employment of natural } \\
\text { environment interpreters }\end{array}$ & $\begin{array}{l}\text { Quality of educational } \\
\text { and interpretive } \\
\text { programs }\end{array}$ & + & $\begin{array}{l}\text { The quality of educational and } \\
\text { interpretive programs improves } \\
\text { with the employment of natural } \\
\text { environment interpreters. }\end{array}$ & [24] \\
\hline $\begin{array}{l}\text { Quality of } \\
\text { educational and } \\
\text { interpretive programs }\end{array}$ & $\begin{array}{l}\text { Tourists' sense of } \\
\text { responsibility }\end{array}$ & + & $\begin{array}{l}\text { Tourists' sense of responsibility is } \\
\text { improved after participating in } \\
\text { environmental education and } \\
\text { interpretive programs. }\end{array}$ & {$[5,24]$} \\
\hline $\begin{array}{l}\text { Tourists' sense } \\
\text { of responsibility }\end{array}$ & $\begin{array}{l}\text { Natural resource } \\
\text { conservation }\end{array}$ & + & $\begin{array}{l}\text { Tourists' sense of responsibility } \\
\text { increases their willingness to pay } \\
\text { for conservation, which leads to } \\
\text { natural resource conservation. }\end{array}$ & [43] \\
\hline $\begin{array}{l}\text { Natural resource } \\
\text { conservation }\end{array}$ & $\begin{array}{l}\text { Sustainability of } \\
\text { ecotourism }\end{array}$ & + & $\begin{array}{l}\text { Ecotourism utilizes nature as the } \\
\text { main source of tourism. } \\
\text { Sustainability of ecotourism is } \\
\text { enhanced with natural resource } \\
\text { conservation efforts. }\end{array}$ & [48] \\
\hline $\begin{array}{l}\text { Sustainability of } \\
\text { ecotourism }\end{array}$ & Number of ecotourists & + & $\begin{array}{l}\text { The number of ecotourists } \\
\text { increases with continued operation } \\
\text { of ecotourism. }\end{array}$ & [48] \\
\hline Number of ecotourists & $\begin{array}{l}\text { Natural resource } \\
\text { conservation }\end{array}$ & - & $\begin{array}{l}\text { Pressure on nature increases with } \\
\text { the increase in the number of } \\
\text { ecotourists, which hinders natural } \\
\text { resource conservation. }\end{array}$ & [42] \\
\hline Number of ecotourists & Profit from ecotourism & + & $\begin{array}{l}\text { Profit from ecotourism increases } \\
\text { with the increase in the number of } \\
\text { ecotourists. }\end{array}$ & [15] \\
\hline Profit from ecotourism & $\begin{array}{l}\text { Ecotourism-related } \\
\text { budget in Korea National } \\
\text { Park Service }\end{array}$ & + & $\begin{array}{l}\text { Ecotourism-related budget in } \\
\text { Korea National Park Service } \\
\text { increases with increased profit } \\
\text { from ecotourism. }\end{array}$ & $\begin{array}{l}\text { State of the case } \\
\text { study site }\end{array}$ \\
\hline $\begin{array}{l}\text { Restriction policy on } \\
\text { the number of national } \\
\text { park visitation }\end{array}$ & Number of ecotourists & none & $\begin{array}{l}\text { The number of ecotourists is } \\
\text { regulated to an appropriate level } \\
\text { through the restriction policy on } \\
\text { the number of national park visits. }\end{array}$ & $\begin{array}{l}\text { State of the case } \\
\text { study site }\end{array}$ \\
\hline
\end{tabular}

4.4.3. Analysis of the Causal Map of the Low-Infrastructure and Government-Initiated Ecotourism System Based on Feedback Thinking

Figure 4 shows a causal map of the low-infrastructure and government-initiated ecotourism system adopted in Jirisan National Park. Ecotourism-related budgets from the Ministry of Environment and Korea National Park Service have been executed through ecotourism-related regulations to support various types of national park ecotourism projects (Eco Institute development project, resident guide program support project and Villages of Excellence designation project). This improves the quality of low-infrastructure tourism resources such as educational and interpretive programs and forms a feedback loop that reinforces the sustainability of ecotourism (Figure 4, R8-R10). These ecotourism projects relieve residents' dissatisfaction with restrictions on their production activities due to the national park designation of Jirisan. In short, these projects create a feedback loop (Figure 4, R11) where the profit from ecotourism is returned to the local economy through the encouragement of resident participation and operation. The reinforcing loops in the map show that government-initiated ecotourism projects tend to settle more easily than resident-led projects in South Korea due to (1) effectiveness in central government funding allocation through the establishment of regulations and (2) active application of ecotourism invigoration plans. 


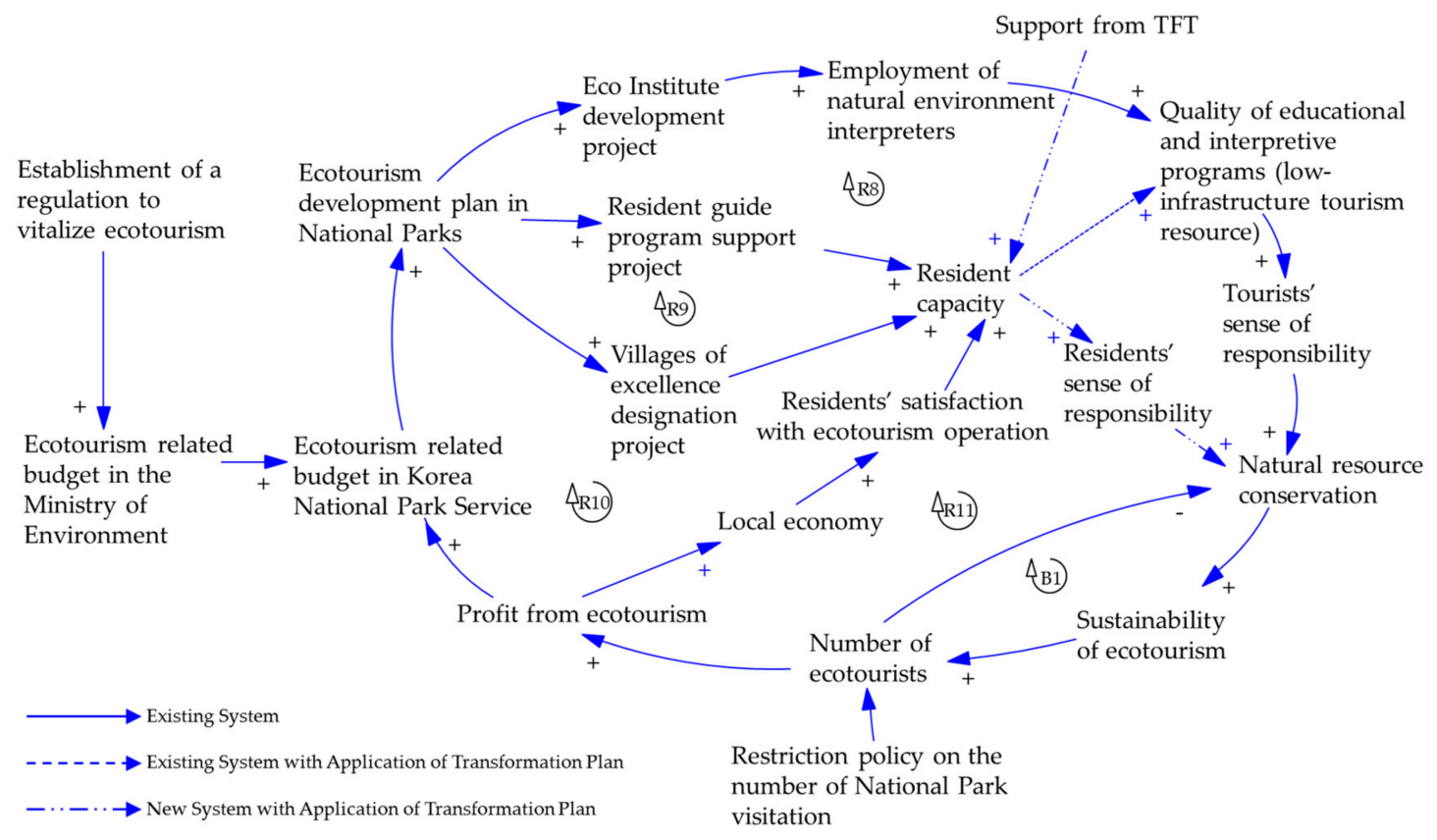

Figure 4. Causal map of the low-infrastructure and government-initiated ecotourism system.

In contrast, a rapid increase in the number of ecotourists due to an ecotourism invigoration policy may harm natural resource conservation in national parks. This creates a feedback loop (Figure 4, B1) that can impede the sustainability of ecotourism. Although a variety of environmental education and interpretive programs are offered through the Korea National Park Service to enhance tourists' sense of responsibility, there is a great possibility of damage to natural resources without the proper management of ecotourists such as mountain climbers. To prevent this, the Korea National Park Service is limiting the number of ecotourism participants and visitors based on the Jirisan National Park's environmental capacity.

4.4.4. Transformation Plan of the Low-Infrastructure and Government-Initiated Ecotourism System Based on Strategic Thinking

The low-infrastructure and government-initiated ecotourism system represented by Jirisan National Park is well managed - based on national policies-but is limited in that it is mostly reliant on financial support from the central government. A plan is needed to transform the system into one with resident-led governance, once government-initiated ecotourism facilities development is completed in the early stage of the Villages of Excellence project. In addition, expert groups from universities and research institutions may establish an ecotourism plan and support a Task Force Team (TFT) that takes charge in resident education to enhance their capacity during the initial stages of resident-led governance formation [8]. Enhanced resident capacity through TFT support can contribute to a heightened sense of responsibility toward natural resources and improve the quality of educational and interpretive programs offered to ecotourists.

\section{Conclusions}

Ecotourism is committed to natural resource conservation, the well-being of the local community and the sustainability of tourism. For the continued prosperity of ecotourism, economic incentives should be offered to (1) conserve local biodiversity and (2) enable sustainable development and poverty elimination by reinforcing local empowerment and increasing employment opportunities. In addition, each tourism stakeholder, including local residents, operators and ecotourists, should be equipped with a strong sense of responsibility toward the environment through nature experiences, 
interpretation and an improved understanding of the local nature, culture and community. This leads to the vitalization of responsible tourism through sustainable ecotourism focused on natural resource conservation and resident initiation. In South Korea, however, ecotourism has been misused for general local development or as a means to implement the government's environmental policy in the name of the wise use of natural resources. The ecotourism industry cannot settle down properly if the aim is the rapid development of the industry or if insufficient consideration is devoted to the principles of ecotourism and the tourism system involving the relationship between supply and demand.

In this context, this study classified types of ecotourism systems based on the scale of infrastructure and the type of operational leadership. It recommended transformation plans for each category selected from cases in Jeollanam-do, South Korea. Based on the literature review, ecotourism systems were classified as (1) low-infrastructure and resident-initiated; (2) high-infrastructure and resident-initiated; (3) high-infrastructure and government-initiated; and (4) low-infrastructure and government-initiated. In addition, a feedback structure was analyzed for each type of ecotourism system.

The analysis of each type of ecotourism system revealed that ecotourists' sense of responsibility was formed in the low-infrastructure types of ecotourism system. This is because low-infrastructure ecotourism, whether it has resident- or government-initiated governance, offers opportunities to foster a sense of responsibility among tourists by providing educational and interpretive programs based on the existing natural resources, culture and heritage instead of expanding tourism infrastructure. A well-managed information platform such as an online home page can help tourists find information on tourism destinations before they travel. Having a quality platform was also found to be effective in enhancing tourists' sense of responsibility. High-infrastructure-based ecotourism destinations tend to rely heavily on the utilization of tourism facilities, which limits the destinations' uniqueness and prevents them from standing out. In addition, the amount of facilities offered at the destination and the quality of management affect the satisfaction level of tourists who have a lower sense of responsibility toward ecotourism. This results in high costs to improve the satisfaction level of tourists who are not willing to bear inconveniences. A solution to this problem is to introduce low-infrastructure ecotourism programs rather than high-infrastructure-based programs. This can foster ecotourists' sense of responsibility and understanding of the need to endure inconveniences while enjoying nature.

Tourism suppliers' competence is required to enhance the sense of responsibility among ecotourists. In most of the resident-initiated ecotourism cases, however, ecotourists' sense of responsibility was found to be weak due to the lack of ability among educational and interpretive program providers and destination information platform managers. Financial and content support from the central government, local self-governing bodies and specialist groups are needed to cultivate the capacity of local program providers and environmental interpreters and to provide seamless management of the information platform. The problem with heavy reliance on government support is that it can lower the possibilities of financial return to the local community and the formation of resident-initiated governance. This raises the need for the establishment of cooperative governance by setting up an appropriate level and range of support. The enhancement of resident competence through cooperative governance can raise tourists' and residents' sense of responsibility, which forms a virtuous circle that leads to voluntary natural resource conservation efforts by tourism suppliers and consumers.

In summary, ecotourism system transformation plans to invigorate responsible tourism are as follows: First, ecotourism systems will be formed, led and operated by local residents-this will help the local community reclaim the profits from ecotourism and the formation of cooperative governance that guarantees an appropriate level of support from the central government, local government and specialist groups is needed to enhance local capacity; second, tourism suppliers will enhance the quality of ecological, cultural and heritage education and interpretive programs and regularly update information platforms, which will strengthen ecotourists' sense of responsibility; thirdly, ecotourists and operators with an enhanced sense of responsibility will maintain the ecotourism system voluntarily for the sustainability of ecotourism based on the understanding of the willingness 
to bear inconveniences within the attraction and the importance of natural resource conservation. The transformation plans proposed in this study can be applied to institutional system and policy development for ecotourism, to the development of guidelines for improving community resilience and to plans for the establishment of biological habitat conservation. This study identified problems in four types of ecotourism systems based on systems thinking and suggested transformation plans to find solutions to the problems. The significance of this research is that it explored solutions to the current problems of indiscriminate ecotourism development led by governments toward the continued sustainability of ecotourism through the vitalization of responsible tourism. It is also meaningful that the study discussed the roles of ecotourism system stakeholders and respective approaches for proper natural resource utilization and conservation for the vitality of responsible tourism. As recommended by the research findings, it is hoped that South Korea's ecotourism system can move in a desirable direction in accordance with internationally understood ecotourism principles. The research is limited in its generalizability, however, in that the analysis of each type of system was based on one case. Further research is recommended to analyze multiple cases in order to identify issues from diverse perspectives.

Acknowledgments: This work was supported by the National Research Foundation of Korea (NRF) grant funded by the Korea government (MEST) (No. 2017R1A2B4008866). We also thank the Tourism Sciences Society of Korea, which provided comments regarding tourism theory at their 79th conference.

Author Contributions: Yun Eui Choi designed the study and participated in all phases. Jinhyung Chon also participated in the development of the study and provided a structural discussion. Minsun Doh and Samuel Park helped conduct the literature review and analyze the results. All of the authors made contributions to the work in this paper.

Conflicts of Interest: The authors declare no conflict of interest.

\section{References}

1. Ayala, H. Resort ecotourism: A master plan for experience management. Cornell Hotel Restaur. Adm. Q. 1996, 37, 54-61. [CrossRef]

2. The International Ecotourism Society (TIES). Available online: http://www.ecotourism.org/what-isecotourism (accessed on 31 October 2017).

3. Choi, Y.E.; Song, K.; Kim, M.; Lee, J. Transformation planning for resilient wildlife habitats in ecotourism systems. Sustainability 2017, 9, 487. [CrossRef]

4. Kiss, A. Is community-based ecotourism a good use of biodiversity conservation funds? Trends Ecol. Evol. 2004, 19, 232-237. [CrossRef] [PubMed]

5. Powell, R.B.; Ham, S.H. Can ecotourism interpretation really lead to pro-conservation knowledge, attitudes and behaviour? Evidence from the Galapagos Islands. J. Sustain. Tour. 2008, 16, 467-489. [CrossRef]

6. Stem, C.J.; Lassoie, J.P.; Lee, D.R.; Deshler, D.D.; Schelhas, J.W. Community participation in ecotourism benefits: the link to conservation practices and perspectives. Soc. Nat. Resour. 2003, 16, 387-413. [CrossRef]

7. Becker-Olsen, K.L.; Cudmore, B.A.; Hill, R.P. The impact of perceived corporate social responsibility on consumer behavior. J. Bus. Res. 2006, 59, 46-53. [CrossRef]

8. Hall, C.M. Governance and Responsible Tourism. In Responsible Tourism: Concepts, Theory and Practice; Lesslie, D., Ed.; CABI: Oxfordshire, UK, 2012; pp. 107-118.

9. Goodwin, H. Taking Responsibility for Tourism; Goodfellow Publishers, Limited: Woodeaton, UK, 2011.

10. Leslie, D. The Responsible Tourism Debate. In Responsible Tourism: Concepts, Theory and Practice; Leslie, D., Ed.; CABI: Oxfordshire, UK, 2012; p. 23.

11. Chiu, Y.-T.H.; Lee, W.-I.; Chen, T.-H. Environmentally responsible behavior in ecotourism: Antecedents and implications. Tour. Manag. 2014, 40, 321-329. [CrossRef]

12. Choi, Y.; You, S.; Ham, E.; Song, K.; Chon, J. Sustainable management plan of eco-tourism resources using system thinking: a case study of Bamseom in Seoul. J. Tour. Sci. 2014, 38, 59-78.

13. Fennell, D.A. Responsible tourism: A Kierkegaardian interpretation. Tour. Recreat. Res. 2008, 33, 3-12. [CrossRef]

14. Wearing, S.; Neil, J. Ecotourism: Impacts, Potentials and Possibilities; Routledge: London, UK, 2009. 
15. Timothy, D. Destination Communities and Responsible Tourism. In Responsible Tourism: Concepts, Theory and Practice; Leslie, D., Ed.; CABI: Oxfordshire, UK, 2012; p. 77.

16. Bookbinder, M.P.; Dinerstein, E.; Rijal, A.; Cauley, H.; Rajouria, A. Ecotourism's support of biodiversity conservation. Conserv. Biol. 1998, 12, 1399-1404. [CrossRef]

17. Gunn, C.A.; Var, T. Tourism Planning: Basics, Concepts, Cases; Psychology Press: London, UK, 2002.

18. Orams, M.B. Types of Ecotourism in Encyclopedia of Ecotourism; CABI: Oxfordshire, UK, 2001.

19. Weaver, D. Ecotourism, 2nd ed.; John Wiley \& Sons: Milton, Australia, 2008.

20. Gunderson, L.H.; Carpenter, S.R.; Folke, C.; Olsson, P.; Peterson, G. Water RATs (resilience, adaptability and transformability) in lake and wetland social-ecological systems. Ecol. Soc. 2006, 11, 16. [CrossRef]

21. Mai, T.; Smith, C. Addressing the threats to tourism sustainability using systems thinking: A case study of Cat Ba Island, Vietnam. J. Sustain. Tour. 2015, 23, 1504-1528. [CrossRef]

22. Richardson, G.P. Problems with causal-loop diagrams. Syst. Dyn. Rev. 1986, 2, 158-170. [CrossRef]

23. Goodwin, M.; Painter, J. Local governance, the crises of fordism and the changing geographies of regulation. Trans. Inst. Br. Geogr. 1996, 21, 635-648. [CrossRef]

24. Hughes, K.; Ballantyne, R. Interpretation in ecotourism settings: Investigating tour guides' perceptions of their role, responsibilities and training needs. J. Tour. Stud. 2001, 12, 2-9.

25. Cheong, S.-M. Privatizing tendencies: Fishing communities and tourism in Korea. Mar. Policy 2003, $27,23-29$. [CrossRef]

26. Lee, G.W.; Choi, H. A study of extracting obstacle factors to activate fishery village: By using FGI of operators of fishery village. Int. J. Tour. Hosp. Res. 2015, 29, 209-220.

27. Kim, Y.; Kim, S.S.; Agrusa, J. An investigation into the procedures involved in creating the Hampyeong Butterfly Festival as an ecotourism resource, successful factors and evaluation. Asia Pac. J. Tour. Res. 2008, 13, 357-377. [CrossRef]

28. Farrell, T.A.; Marion, J.L. The protected area visitor impact management (PAVIM) framework: A simplified process for making management decisions. J. Sustain. Tour. 2002, 10, 31-51. [CrossRef]

29. Fennell, D.A. Ecotourism; Routledge: London, UK, 2014.

30. Responsible Travel. Available online: https://www.responsibletravel.com (accessed on 29 August 2017).

31. Frey, N.; George, R. Responsible tourism management: The missing link between business owners' attitudes and behaviour in the Cape Town tourism industry. Tour. Manag. 2010, 31, 621-628. [CrossRef]

32. Spenceley, A.; Relly, P.; Keyser, H.; Warmeant, P.; McKenzie, M.; Mataboge, A.; Norton, P.; Mahlangu, S.; Seif, J. Responsible tourism manual for South Africa, department for environmental affairs and tourism, July 2002. Responsib. Tour. Man. S. Afr. 2002, 2. [CrossRef]

33. Cater, E. Ecotourism in the third world: Problems for sustainable tourism development. Tour. Manag. 1993, 14, 85-90. [CrossRef]

34. Western, D. Defining ecotourism. In Ecotourism: A Guide for Planners and Managers; Lindberg, K., Hawkins, D., Eds.; The Ecotourism Society: North Bennington, VT, USA, 1993; pp. 7-11.

35. Croall, J. Preserve or Destroy: Tourism and the Environment; Calouste Gulbenkian Foundation: London, UK, 1995.

36. The International Ecotourism Society (TIES). Available online: http:/ / www.ecotourism.org (accessed on 31 October 2017).

37. World Tourism Organization (UNWTO). Global Code of Ethics for Tourism. Available online: http:/ / cf.cdn. unwto.org/sites/all/files/docpdf/guidelinesgcetcommitmenten.pdf (accessed on 31 October 2017).

38. Cape Town Declaration. Cape Town Conference on Responsible Tourism in Destinations. Available online: http:/ / www.capetown.gov.za (accessed on 31 October 2017).

39. UNWTO. The Responsible Tourist and Traveller. Available online: http:/ / ethics.unwto.org/sites/all/files / docpdf/responsibletouristbrochureen.pdf (accessed on 31 October 2017).

40. Chafe, Z. Consumer Demand and Operator Support for Socially and Seam Less Environmentally Responsible Tourism; Working Paper No. 104; Center on Ecotourism and Sustainable Development/The International Ecotourism Society: Washington, DC, USA, 2004.

41. Weeden, C. Ethical tourism: An opportunity for competitive advantage? J. Vacat. Mark. 2002, 8, 141-153. [CrossRef]

42. Budeanu, A. Sustainable tourist behaviour? A discussion of opportunities for change. Int. J. Consum. Stud. 2007, 31, 499-508. [CrossRef] 
43. Leslie, D. The consumers of tourism. In Responsible Tourism: Concepts, Theory and Practice; Leslie, D., Ed.; CABI: Oxfordshire, UK, 2012; pp. 54-71.

44. Stronza, A. The economic promise of ecotourism for conservation. J. Ecotour. 2007, 6, 210-230. [CrossRef]

45. Lee, Y.J.; Song, Y.M.; Yoon, J.H. Discussion on the fairness in tourism phenomenon: Focused on the tourism system. J. Tour. Sci. 2012, 36, 35-57.

46. Choi, Y.E.; Kim, J.J.; Jung, D.H.; Song, D.J.; You, S.; Chon, J. Social-ecological system dynamics of restoration of asiatic black bears and management planning in national park. Korean Syst. Dyn. Rev. 2017, 18, 87-114.

47. Mihalic, T. Sustainable-responsible tourism discourse-Towards 'responsustable' tourism. J. Clean. Prod. 2016, 111, 461-470. [CrossRef]

48. Baral, N. Evaluation and resilience of ecotourism in the Annapurna conservation area, Nepal. Environ. Conserv. 2014, 41, 84-92. [CrossRef]

49. Filo, K.R.; Funk, D.C.; O'Brien, D. It's really not about the bike: Exploring attraction and attachment to the events of the Lance Armstrong Foundation. J. Sport Manag. 2008, 22, 501-525. [CrossRef]

50. McCool, S.F. Constructing partnerships for protected area tourism planning in an era of change and messiness. J. Sustain. Tour. 2009, 17, 133-148. [CrossRef]

51. Ministry of Environment. Eco-tourism Activation Master Plan; Government Report; Ministry of Environment: Sejong, Korea, 2014.

52. Ministry of Culture, Sports and Tourism. A Study on the Improvement of Performance and Selection and Evaluation System of Culture and Tourism Festival; Government Report; Ministry of Culture, Sports and Tourism: Sejong, Korea, 2014.

53. Korea National Park Ecotour. Available online: http:/ / ecotour.knps.or.kr/ (accessed on 31 October 2017).

54. Korea National Park Myeong-Pum Maeul. Available online: http://www.knps.or.kr/portal/main/contents. do?menuNo (accessed on 31 October 2017).

(C) 2017 by the authors. Licensee MDPI, Basel, Switzerland. This article is an open access article distributed under the terms and conditions of the Creative Commons Attribution (CC BY) license (http:/ / creativecommons.org/licenses/by/4.0/). 